\title{
Effects of collagen-induced rheumatoid arthritis on amyloidosis and microvascular pathology in APP/PS1 mice
}

Sun Mi Park ${ }^{1,3}$, Jin Hee Shin ${ }^{3}$, Gyeong Joon Moon ${ }^{2}$, Sung Ig Cho ${ }^{3}$, Yong Beom Lee ${ }^{3}$ and Byoung Joo Gwag ${ }^{1,3^{*}}$

\begin{abstract}
Background: Evidence suggests that rheumatoid arthritis (RA) may enhance or reduce the progression of Alzheimer's disease (AD). The present study was performed to directly explore the effects of collagen-induced rheumatoid arthritis (CIA) on amyloid plaque formation, microglial activation, and microvascular pathology in the cortex and hippocampus of the double transgenic APP/PS1 mouse model for AD. Wild-type or APP/PS1 mice that received type II collagen (CII) in complete Freund's adjuvant (CFA) at 2 months of age revealed characteristics of RA, such as joint swelling, synovitis, and cartilage and bone degradation 4 months later. Joint pathology was accompanied by sustained induction of IL- $1 \beta$ and TNF- $\alpha$ in plasma over 4 weeks after administration of CII in CFA.

Results: CIA reduced levels of soluble and insoluble amyloid beta (AB) peptides and amyloid plaque formation in the cortex and hippocampus of APP/PS1 mice, which correlated with increased blood brain barrier disruption, Iba1-positive microglia, and CD45-positive microglia/macrophages. In contrast, CIA reduced vessel density and length with features of microvascular pathology, including vascular segments, thinner vessels, and atrophic string vessels.
\end{abstract}

Conclusions: The present findings suggest that RA may exert beneficial effects against A $\beta$ burden and harmful effects on microvascular pathology in AD.

\section{Background}

Alzheimer's disease (AD) is characterized by extracellular $\mathrm{A} \beta$ deposition, intracellular neurofibrillary tangles, neuronal loss, and cerebral microvascular pathology, resulting in progressive learning and memory deficits [1-3]. Extensive evidence supports a dynamic role for inflammation in the AD pathogenesis. Microglia, the macrophages that reside in the central nervous system, are activated around $A \beta$ deposits in the brains of $A D$ patients [4]. Levels of inflammatory mediators including TNF- $\alpha$ and C-reactive protein (CRP) are also increased in the peripheral blood of $\mathrm{AD}$ patients $[5,6]$ and associated with increased risk of $\mathrm{AD}[7,8]$. Activated microglia/macrophages derived from the brain and blood produce chemokines, cytokines, and free radicals, which participate in $A \beta$ plaque formation and the neurodegenerative process in $\mathrm{AD}$ [9-13].

\footnotetext{
* Correspondence: bjgwag5001@gmail.com

'Department of Pharmacology, Ajou University School of Medicine, Suwon, South Korea

Full list of author information is available at the end of the article
}

Several epidemiological studies have demonstrated that the relative risk of $A D$ is significantly reduced in rheumatoid arthritis (RA) patients treated with nonsteroidal anti-inflammatory drugs (NSAIDs) for longer than 2 yrs [14,15]. In meta-analysis of 17 epidemiological studies, protective effects of arthritis and anti-inflammatory drugs have been observed against AD [15]. These studies have raised the hypothesis that anti-inflammatory drug treatment protects against $\mathrm{AD}$, but arthritis or RA itself could modulate AD risk. Cyclooxygenase-2 (COX2), an inducible cyclooxygenase known to mediate inflammation in $\mathrm{RA}$ and $\mathrm{AD}$, has been proposed as a positive regulator for amyloid plaque formation and cognitive deficit in AD. In support of this hypothesis, administration of ibuprofen, a mixed COX-1/COX-2 inhibitor, reduces microglial activation, $\mathrm{A} \beta$ production, plaque burden, and cognitive impairment in Tg2576 mice $[16,17]$. Amyloid plaque formation is enhanced in APP/PS1 mice overexpressing human COX-2 [18]. However, the beneficial effects of NSAIDs have not been verified in randomized, double-blind, placebo- 
controlled clinical trials for AD patients [19]. In such clinical trials, NSAIDs were administered for less than 1 yr due to increased risk of acute myocardial infarction in patients receiving NSAIDs for longer than 18 months [20]. In a recent report from Alzheimer's disease antiinflammatory prevention trial (ADAPT) with NSAIDs, treatment of asymptomatic individuals with naproxen for $2 \mathrm{yr}$ was shown to reduce incidence of AD after 2 to $3 \mathrm{yr}$ [21]. Therefore, the preventive and disease-modifying potential of NSAIDs remains to be determined in AD patients treated with NSAIDs for a long period of time ( $>2$ yrs).

In a recent study, amyloid plaque formation and cognitive impairment were reduced in AD mice that were subjected to subcutaneous administration of granulocyte-macrophage colony-stimulating factor (GM-CSF), an inflammatory cytokine shown to increase in RA, for $20 \mathrm{~d}$ [22]. Combined with findings from epidemiological studies indicating that the incidence of $\mathrm{AD}$ is reduced in RA patients with prolonged NSAID treatment, RA is expected to directly modulate AD onset and progression. To examine this hypothesis, 2-month-old APP/PS1 mice were injected with bovine type II collagen (CII) in complete Freund's adjuvant (CFA), which has been widely used to induce RA in rodents [23]. A $\beta$ burden, microglia/macrophages, and cerebral vascular pathology were investigated in APP/PS1 mice 4 months after the injections of CII in CFA to determine whether RA directly modulates amyloidosis and microvascular pathology in $\mathrm{AD}$.

\section{Results}

Induction of collagen-induced arthritis (CIA) in APP/PS1 mice

APP/PS1 mice and wild-type littermates injected with CII in CFA revealed pathologic features of RA. Paw swelling and redness of the joint were manifest immediately after the second immunization, reached a peak 1 month later, and significantly persisted over the next 4 months when animals were sacrificed (Figure 1A, P $<0.05)$. In contrast to CIA induced paw swelling in all four paws in DBA/1 mice [23], paw swelling was confined to the injection site in wild-type and APP/PS1 mice. Plasma levels of the pro-inflammatory cytokines IL- $1 \beta$ and TNF- $\alpha$ were increased within $1 \mathrm{~d}$ after the second immunization and remained elevated over the next 4 weeks in wild-type and APP/PS1 mice (Figure $1 \mathrm{~B}, \mathrm{P}<0.05)$. Paraffin-embedded joint sections stained with hematoxylin and eosin revealed severe bone erosion, cartilage/chondrocyte degradation, and proliferative synovitis in wild-type (Figure $1 \mathrm{C}$ ) at 4 months after the second immunization. Such joint pathology was similar in APP/PS1 mice treated with CIA (data not shown).

\section{Effects of CIA on amyloid plaque pathology in APP/PS1 mice}

We examined the effect of CIA on $A \beta$ deposition in APP/PS1 mice. APP/PS1 mice received CII in CFA at 2 months of age before $A \beta$ deposition was evolved. When $\mathrm{A} \beta$ deposition was analyzed 4 months after CIA, levels of $\mathrm{A} \beta$ deposition were moderate in APP/PS1 mice [24]. $A \beta$ plaques were widespread in the cerebral cortex and hippocampus of 6-month-old APP/PS1 mice (Figure 2A). Contrary to expectations, CIA substantially reduced $A \beta$ plaque accumulation in APP/PS1 mice. Image analysis of $A \beta$ deposition showed that $A \beta$ plaques that were positive for $4 \mathrm{G} 8$ or thioflavine-S were significantly reduced in the cerebral cortex and hippocampus of 6month-old APP/PS1 mice treated with CIA, compared with vehicle-treated APP/PS1 mice (Figure 2B). The effect of CIA on $A \beta$ levels was analyzed in the opposite hemisphere using an ELISA that detects SDS-soluble and SDS-insoluble $A \beta 40$ and $A \beta$ 42. Levels of soluble $\mathrm{A} \beta 40$ and $\mathrm{A} \beta 42$ appeared reduced by $48 \%(P=0.056)$ and $20 \%(P=0.026)$ in APP/PS1 mice 4 months after CIA, respectively, compared with vehicle-treated APP/ PS1 mice. APP/PS1 mice treated with CIA revealed substantially significant reduction in levels of insoluble $A \beta$ 40 and $\mathrm{A} \beta 42$ (Figure $2 \mathrm{C}, \mathrm{P}<0.05$ ).

\section{Enhanced activation of microglia/macrophage in APP/PS1 mice 4 months after $\mathrm{ClA}$}

CIA-induced systemic inflammation likely triggers brain inflammation that contributes to internalization and degradation of $A \beta$ through activated microglia. Iba- 1 or Mac-1-immunoreactive microglial cells were observed in the brains of wild-type mice and increased in the brains of APP/PS1 mice at 6 months of age (Figure 3A). Immunoreactive Mac-1 positive cells were transiently increased in the cortex and hippocampus of wild-type mice over the course of $1 \mathrm{~d}$ after the second immunization injection. However, by 2 weeks after CIA Mac- 1 immunoreactivity had returned to levels that were comparable to the levels in vehicle-injected mice (Additional file 1). In APP/PS1 mice treated with CIA, the number of Iba-1 or 1-immunoreactive cells in the cerebral cortex and hippocampus increased 4 months later. CD45-positive activated microglia or macrophages were not observed in wild-type mice at 4 months after CIA (Figure $3 \mathrm{~A}$ ). Activated microglia or macrophages were observed in the cortex of 6-month-old APP/PS1 mice and increased in the cerebral cortex and hippocampus of APP/PS1 mice treated with CIA up to approximately $210 \%$ (the number of CD45-immunoreactivity) and $230 \%$ (the area of CD45-immunoreactivity) (Figure 3A, $\mathrm{B}, P<0.05)$. Immunoreactivity to IL- $1 \beta$ and TNF- $\alpha$ was increased in microglia and astrocytes in the molecular layer of the dentate gyrus of APP/PS1 mice compared 


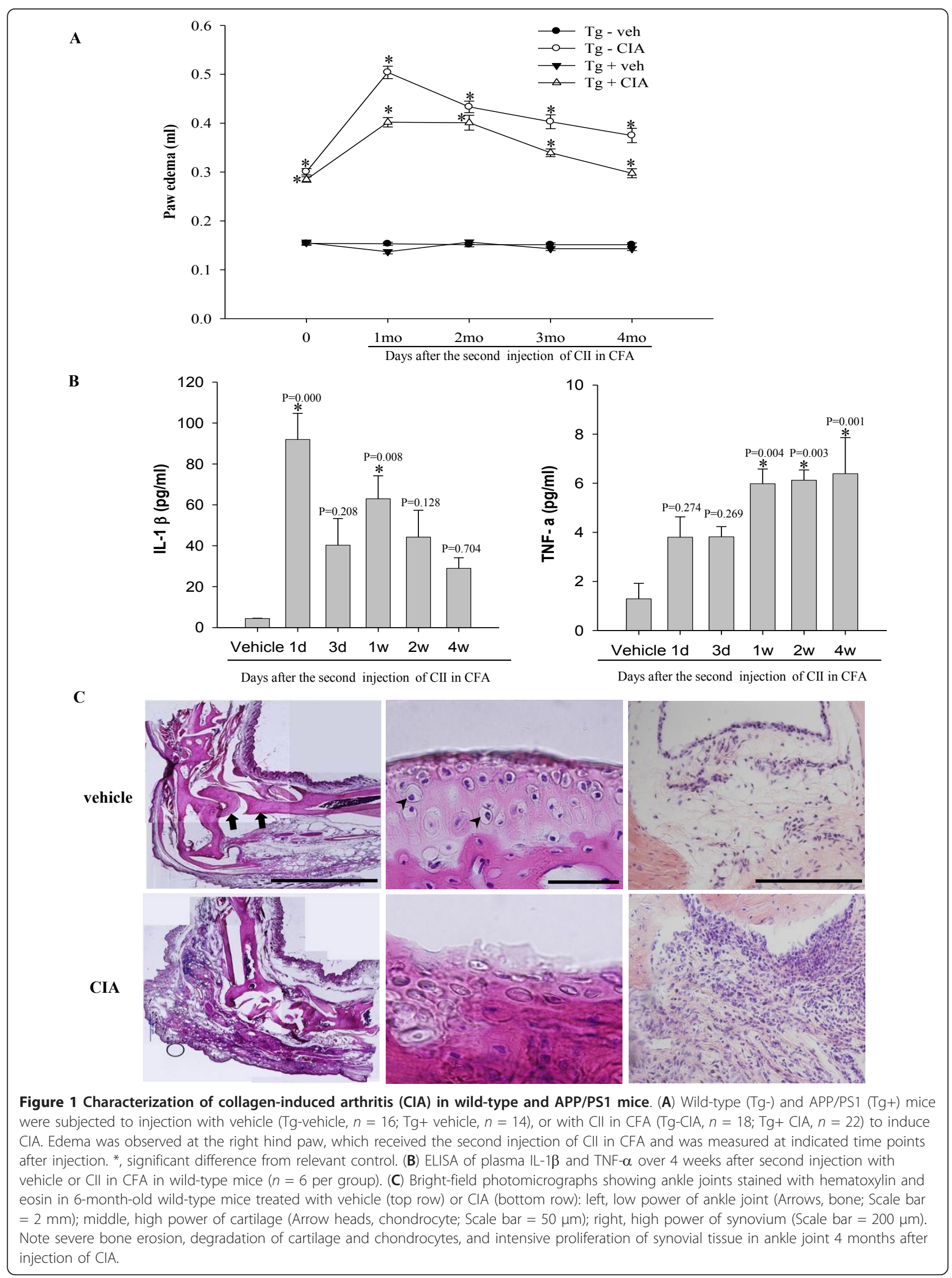




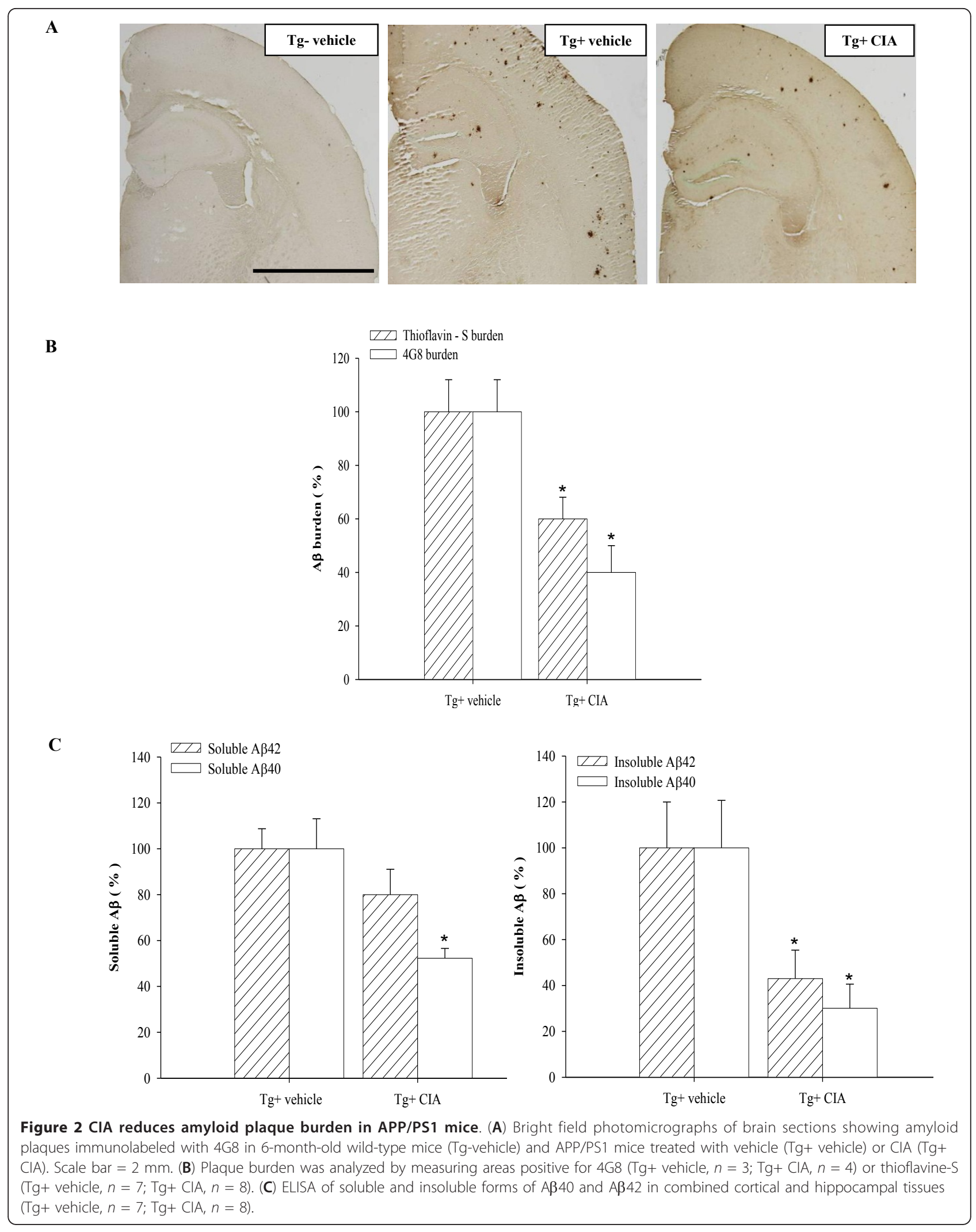




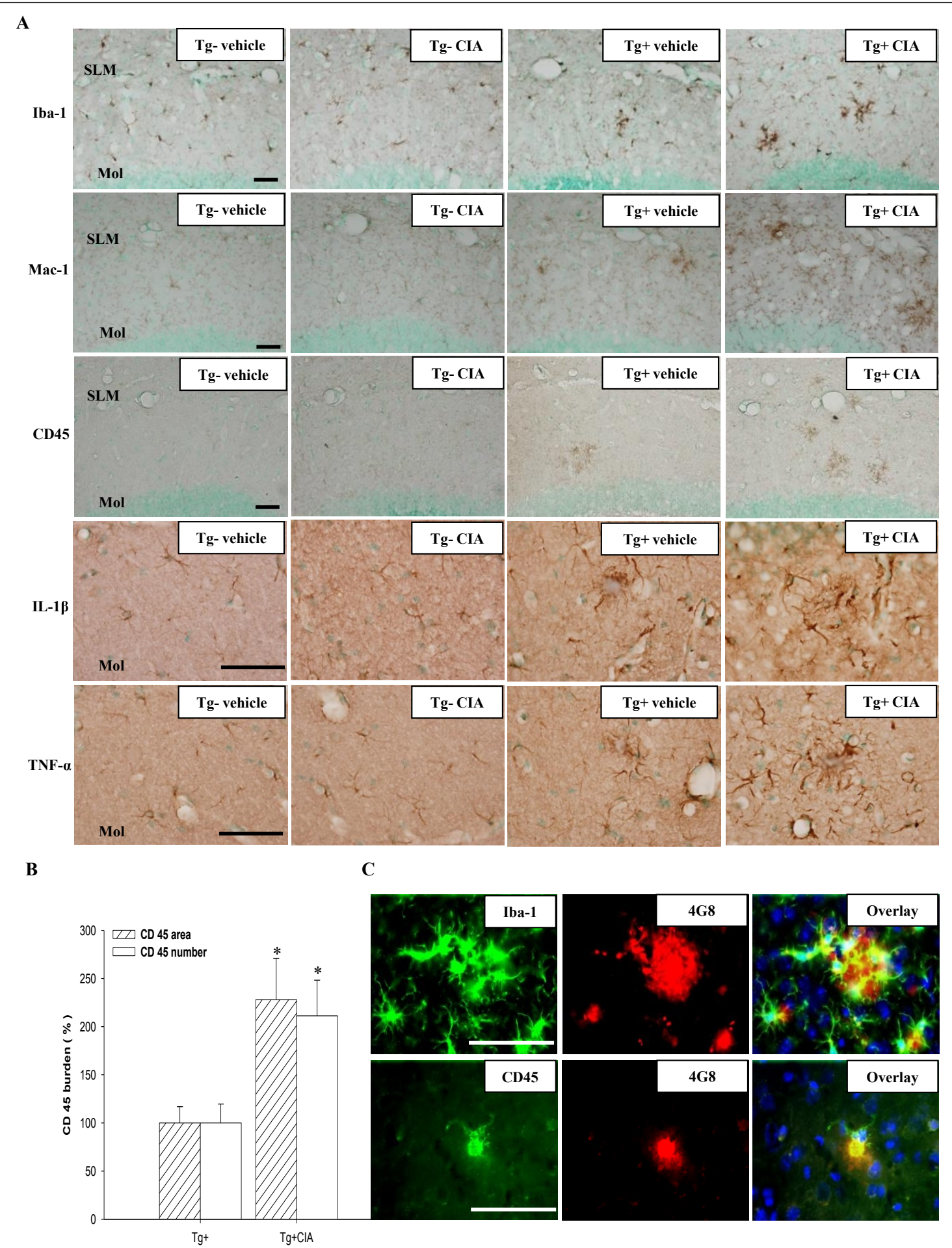

Figure $3 \mathrm{CIA}$ enhances activation of microglia/macrophages in APP/PS1 mice. (A) Photomicrographs of the dentate gyrus molecular layer immunolabeled with antibodies against Iba-1, Mac-1, CD45, IL-1 $\beta$, and TNF- $\alpha 4$ months after injection of 2-month-old wild-type (Tg-) and APP/ PS1 mice (Tg+) with vehicle or CIA. SLM, stratum lacunosum molecular; Mol, dentate gyrus molecular layer. Scale bar = $50 \mu$ m. (B) Activation of microglia/macrophages was analyzed by measuring the area and the number of CD45-immunoreactivity in the hippocampal and cortical regions $(\mathrm{Tg}+$ vehicle, $n=3 ; \mathrm{Tg}+\mathrm{CIA}, n=4)$. (C) Fluorescence photomicrographs showing Iba-1 and CD45 signal around 4G8-positive amyloid plaques in the cortex of CIA-treated APP/PS1 mice. Top row, triple staining with Iba-1, 4G8, and DAPI (a nuclear marker); bottom row, triple staining with CD45, 4G8, and DAPI. Scale bar $=200 \mu \mathrm{m}$. 
to wild-type as previously reported [25-27]. CIA further increased expression of IL- $1 \beta$ and TNF- $\alpha$ in APP/PS1 mice (Figure 3A). In CIA-treated APP/PS1 mice, Iba-1positive or $\mathrm{CD} 45$-positive cells were observed adjacent to $\mathrm{A} \beta$ plaques (Figure $3 \mathrm{C}$ ).

\section{Effects of CIA on permeability of the blood-brain barrier (BBB) in APP/PS1 mice}

CIA has been shown to increase BBB permeability in DBA/1 mice [28]. CIA likely causes the infiltration of monocytes and activation of microglia/macrophages that contribute to clearance of A $\beta$ peptide in APP/PS1 mice [29]. Immunoreactivity to a macrophage mannose receptor (CD206) antibody was observed sparsely in the perivascular and leptomeningeal regions of wildtype and APP/PS1 mice. CD206-positive macrophages were increased in the vicinity of vessels in wild-type and APP/PS1 mice subjected to CIA (Figure 4A), suggesting the possibility that CIA induces the migration of macrophages into the brain parenchyma through the disrupted BBB. In support of this hypothesis, levels of immunoglobulin G (IgG) were significantly increased in the brains of wild-type and APP/PS1 mice 1.5 and 4 months after CIA compared with relevant vehicle (Figure $4 \mathrm{~B}$ and $4 \mathrm{C}$ ).

\section{CIA induces cerebral microvascular pathology in APP/PS1 mice}

Finally, we examined whether CIA would cause cerebrovascular pathology. Cerebral microvessels were immunolabeled with an anti-collagen type IV antibody, a marker of the endothelial basement membrane. CIA significantly reduced vascular density and length in the cerebral cortex and hippocampus of APP/PS1 mice 4 months later (Figure 5, A and 5B). CIA also induced cerebral microvascular pathology, such as vascular segments and atrophic string vessels (Figure 5C). At 4 months after the injection procedure, survival of vehicle-treated APP/PS1 mice was approximately 93.3\%, while the survival of CIA-treated mice was reduced to 76.9\% (Additional file 2).

\section{Discussion}

Administration of CII in CFA produces features of RA including joint swelling, bone and cartilage degeneration, synovitis, and infiltration of inflammatory cells at the injection sites accompanied by sustained elevation of IL- $1 \beta$ and TNF- $1 \beta$ in plasma of wild-type and APP/PS1 mice. CIA reduces levels of $A \beta$ and plaque burden in the cortex and hippocampus of APP/PS1 mice. The reduced amyloidosis is associated with $\mathrm{BBB}$ disruption and activation of microglia/macrophage. In contrast to the clearance of $A \beta$ plaques, CIA enhances microcerebral pathology and mortality in APP/PS1 mice.
Inflammation can reduce amyloidosis and cognitive deficit in transgenic mouse models of AD. Amyloid plaque formation is enhanced in APP/PS1 mice overexpressing human COX-2, the inducible isoform of cyclooxygenase that is essential for prostaglandin E2 $\left(\mathrm{PGE}_{2}\right)$-mediated inflammation [30]. Chronic administration of ibuprofen, a mixed COX-1/COX-2 inhibitor, prevents microglial activation, and reduces levels of inflammatory cytokines, $A \beta$, and amyloid plaque formation in $\operatorname{Tg} 2576$ mice $[16,17,31]$. The administration of COX-2 inhibitors prevents $A \beta$-mediated suppression of long-term plasticity and improves synaptic plasticity in Tg2576 [18]. COX-2-mediated $\mathrm{PGE}_{2}$ production can enhance amyloidosis by reducing the phagocytic function of microglia and stimulating $A \beta$ production through activation of the prostaglandin E2 and E4 receptors [32,33].

Several lines of evidence suggest that inflammation negatively regulates amyloidosis and cognitive deficit in transgenic mouse models of AD. Overexpression of TGF- $\beta 1$ or IL- 6 reduces amyloid plaque formation through microglial activation in Tg2576 and TgCRND8 mice $[34,35]$. Administration of G-CSF or M-CSF induces brain inflammation and ameliorates amyloid pathology and cognitive deficit in transgenic AD mice, including $\mathrm{Tg} 2576$ [36,37]. The intracerebral infection of Borna disease virus, which induces microglial cell activation, also reduces amyloid plaque formation in Tg2576 mice [38]. Furthermore, overexpression of soluble complement receptor-related protein $\mathrm{y}$, a complement inhibitor, reduces microglial activation, produces neurodegeneration, and enhances $A \beta$ production and accumulation in human amyloid precursor protein transgenic mice bearing the amyloidogenic K670M, N671L, and V717F mutations [39].

$A \beta$ produced in the brains of APP/PS1 mice or AD patients induces the expression and secretion of chemotactic cytokines, such as monocyte chemotactic protein 1 , which enhances the transmigration and differentiation of monocytes from the bloodstream [40-42]. Circulating monocytes are increased in CIA-treated mice or RA patients, and are expected to transmigrate through the $\mathrm{BBB}$ into the brain areas exposed to $\mathrm{A} \beta$. The brain monocytes can be differentiated into macrophages by cytokines such as M-CSF and IL-6, which are induced by A $\beta$ or after CIA [35,43-47]. Macrophages and activated microglia contribute to $A \beta$ clearance. Alternatively, CIA may reduce the $A \beta$ plaque burden by increasing passive transport to the periphery through increased BBB disruption.

$A \beta$ accumulation in the cerebral vessel triggers $B B B$ disruption by reducing the expression of tight junction proteins such as occludin, claudin-5, and zona occludins$1[48]$. A $\beta$ can induce oxidative stress, mitochondrial 


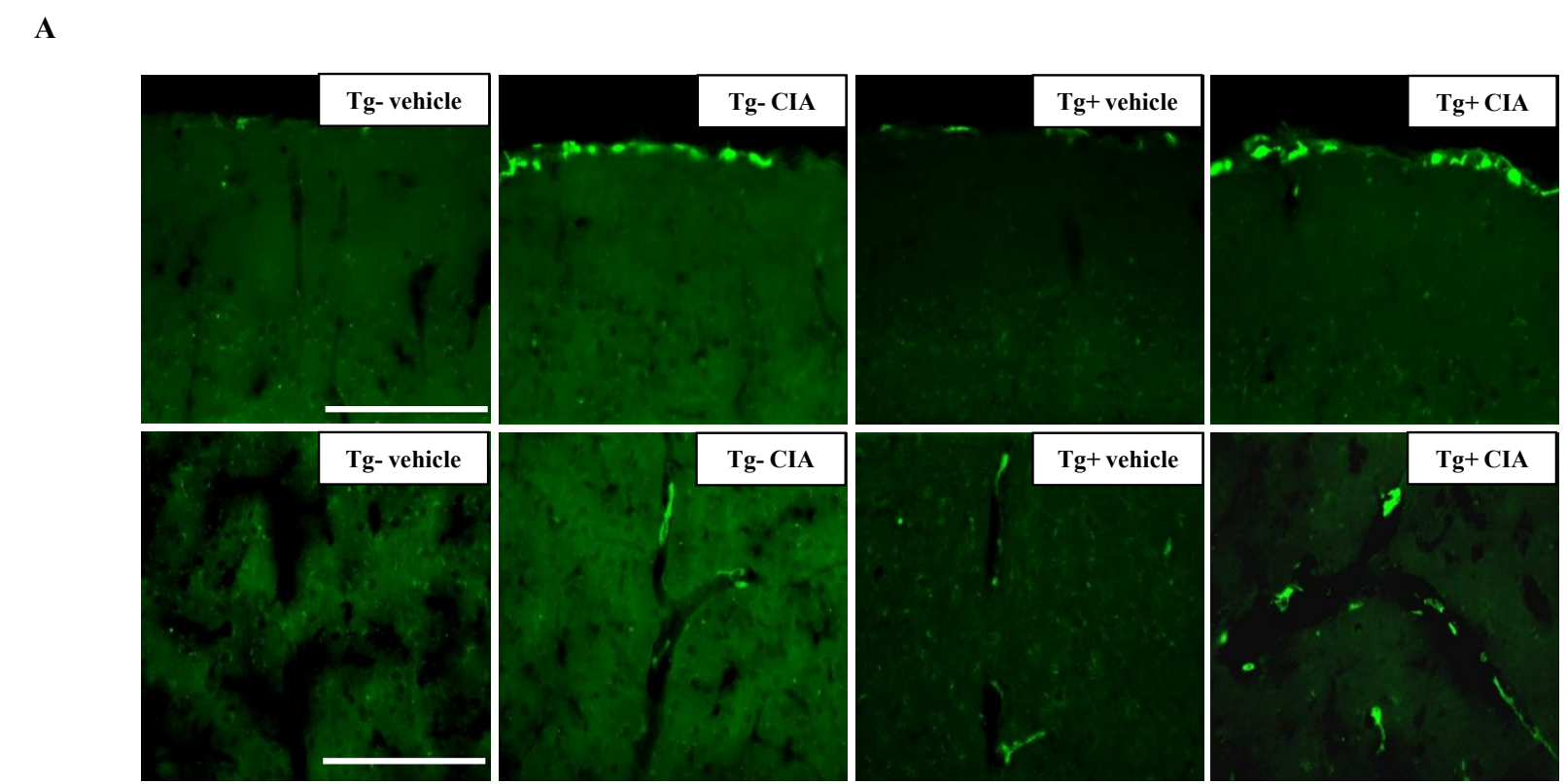

B

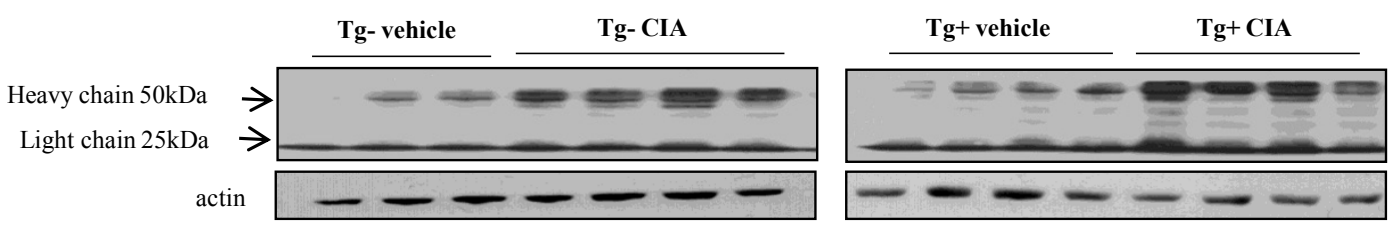

C
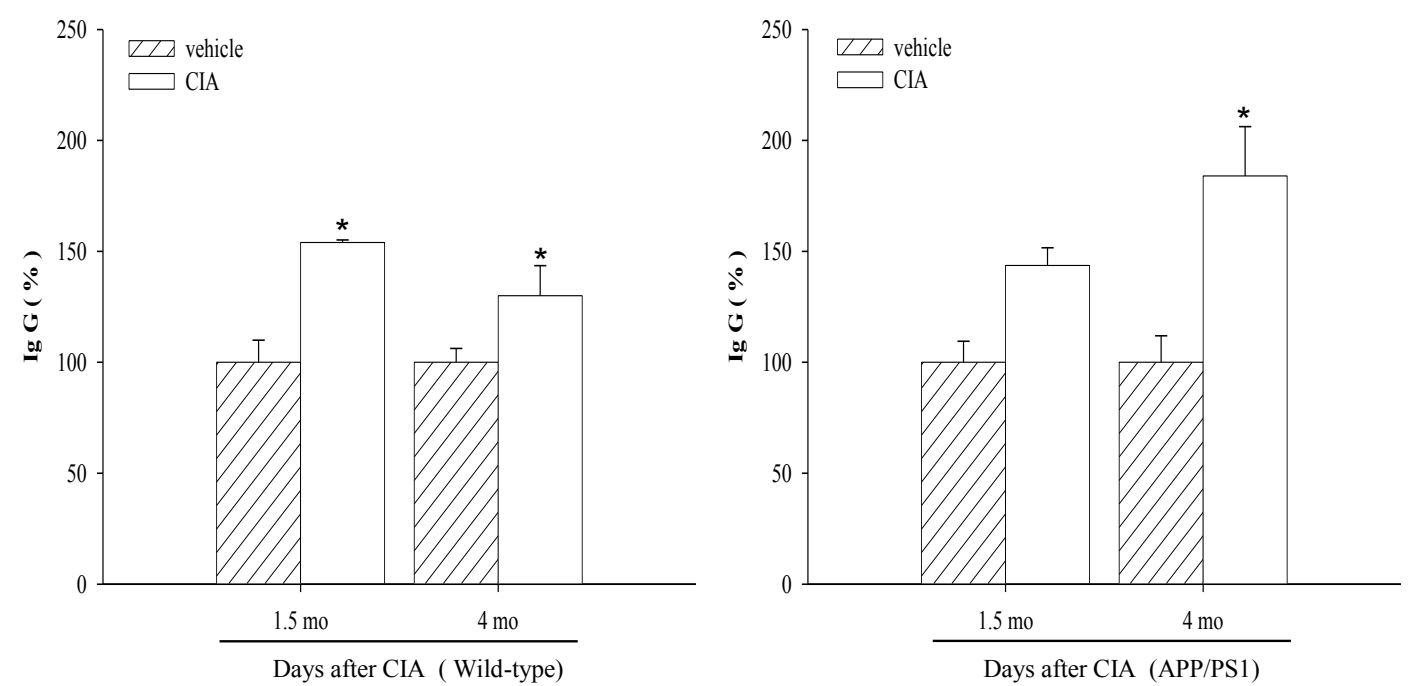

Figure $4 \mathrm{CI}$ enhances macrophages at the leptomeningeal and perivascular regions and BBB permeability in APP/PS1 mice. (A) Fluorescence photomicrographs of cortical areas immunolabeled with rat monoclonal anti-CD206 4 months after injection of 2-month-old wildtype ( $\mathrm{Tg}-$ ) and APP/PS1 ( $\mathrm{Tg}+$ ) mice with vehicle or CIA. Note increased leptomeningeal (top row) and perivascular (bottom row) macrophages in $\mathrm{Tg}$ - and $\mathrm{Tg}+$ mice treated with CIA. Scale bar $=200 \mu \mathrm{m}$. (B) Western blot of lgG in combined cortical and hippocampal samples 4 months after CIA injection into $\mathrm{Tg}$ - and $\mathrm{Tg}+$ mice. (C) IgG levels were analyzed 1.5 months ( $\mathrm{Tg}$ - vehicle, $n=3 ; \mathrm{Tg}$ - CIA $n=3 ; \mathrm{Tg}+$ vehicle, $n=3 ;$ and $\mathrm{Tg}+\mathrm{CIA}, n=4$ ) and 4 months after vehicle or CIA injection into $\mathrm{Tg}$ - and $\mathrm{Tg}$ + mice (Tg-vehicle, $n=3$; $\mathrm{Tg}$ - CIA, $n=4$; $\mathrm{Tg}$ + vehicle, $n=4 ;$ and $\mathrm{Tg}+\mathrm{CIA}, n=4$ ). 


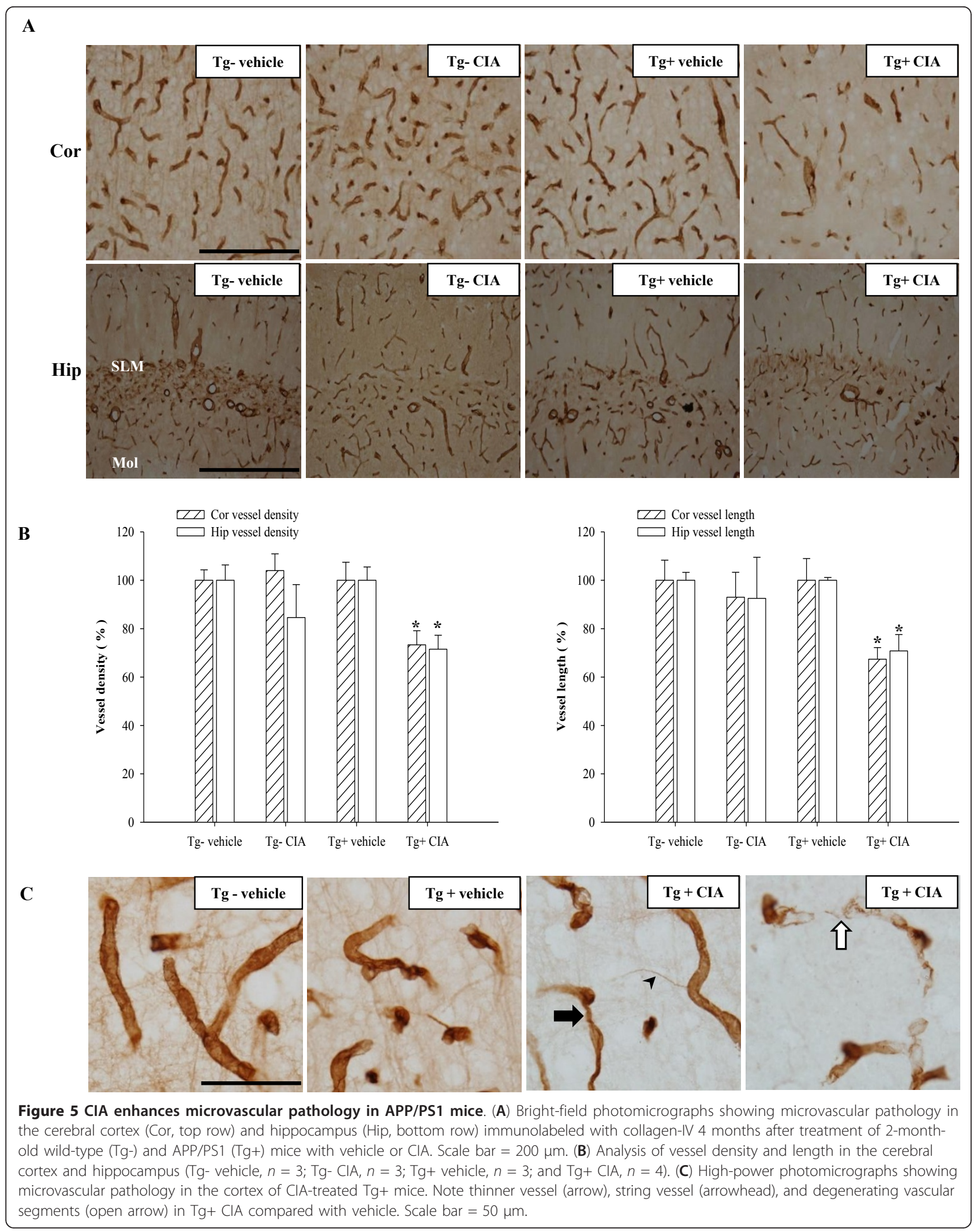


dysfunction, and the activation of caspase-dependent apoptotic pathways, possibly through mechanisms involving interaction with RAGE, resulting in endothelial cell degeneration [48-50]. In the present study, we provide evidence that CIA-treated APP/PS1 mice develop vascular segments and atrophic string vessels characteristic of cerebrovascular pathology observed in AD patients.

Alzheimer's disease is occasionally accompanied by epileptic seizures [51]. Cortical and hippocampal seizures are detected in three different APP transgenic mice models of AD [52]. Seizures are frequently observed in APP/PS1 mice at 3 and 4.5 months of age and correlated with mortality that peaks at 3 to 4 months of age [53]. In the present study, two APP/PS1 mice died at 3 to 4 months of age (6.7\% mortality). In thirty nine APP/PS1 mice treated with CIA, nine mice died at 3 to 4 months of age ( $23.1 \%$ mortality). Thereafter, no death was observed. Thus, CIA may increase mortality of APP/PS1 mice by enhancing seizures, which is likely related with sustained inflammation and enhanced cerebrovascular pathology.

While further study is needed to delineate mechanisms underlying the effects of CIA on vascular pathology, elevated monocytes and neutrophils in CIA-treated APP/PS1 mice likely migrate to the cerebral vessel, release cytotoxic molecules such as superoxide, matrix metalloproteases, and TNF- $\alpha$, and then contribute to endothelial cell degeneration and mortality in a cooperative way with $A \beta$. Recently, systemic administration of lipopolysaccharide for 6 weeks was shown to induce sustained microglial activation and tau hyperphosphorylation in the hippocampus of $3 \mathrm{X}$ Tg-AD mice harboring three mutant human genes $\left(\mathrm{APP}_{\mathrm{K} 670 \mathrm{~N} ; \mathrm{M} 671 \mathrm{~L}}, \mathrm{PS}_{\mathrm{M} 146 \mathrm{~V}}\right.$, and tau $\left.\mathrm{P}_{\mathrm{P} 301 \mathrm{~L}}\right)$ [54]. Considering that lipopolysaccharide triggers systemic inflammation and $\mathrm{BBB}$ disruption, CIA may exacerbate tau pathology as well as vascular pathology in AD.

\section{Conclusions}

CIA induced before the onset of amyloid pathology reduces $\mathrm{A} \beta$ burden over 4 months in APP/PS1 mice, presumably by enhancing the clearance and efflux of $A \beta$. However, such beneficial effects of CIA are accompanied by enhanced microvascular pathology and mortality. The present findings suggest that transient systemic inflammation may be beneficial in lowering $A \beta$ burden; however, the chronic systemic inflammation demonstrated in RA is a serious risk factor for cerebral microvascular pathology and hypoperfusion in $\mathrm{AD}$, which likely lead to neurodegeneration and cognitive deficit.

\section{Methods}

\section{Animal Preparation}

All experiments were performed in accordance with the Guideline for Animal Experiments of Ajou
University and GNT Pharma. APP/PS1 mice (APPswe/PS1dE9) were purchased from the Jackson Laboratory (Bar Harbor, ME, USA). These mice were generated by co-injection of chimeric APPswe (K595N, M596L) and an exon-9-deleted PS1 variant (dE9) vector controlled by a mouse prion promoter [55]. Male APP/PS1 transgenic mice were cross-bred with B6C3F1/J background females. APP/PS1 mice $(\mathrm{Tg}+)$ and wild-type littermates $(\mathrm{Tg}-)$ were determined by PCR analysis of tail DNA.

\section{Induction of $\mathrm{CIA}$}

Bovine CII (Chondrex, Redmond, WA, USA) was dissolved in $0.1 \mathrm{M}$ acetic acid at a $4 \mathrm{mg} / \mathrm{ml}$ by stirring overnight at $4{ }^{\circ} \mathrm{C}$, added to an equal volume of CFA (Chondrex), and homogenized as described previously [23]. To induce CIA, 2-month-old female $\mathrm{Tg}+$ and $\mathrm{Tg}$ mice were injected intradermally at the tail base with $0.1 \mathrm{ml} \mathrm{CII} \mathrm{in} \mathrm{CFA} \mathrm{or} 0.1 \mathrm{ml}$ mineral oil as a vehicle. The animals received another injection of CII in CFA or mineral oil at the right hind paw $14 \mathrm{~d}$ after the primary immunization. Paw edema was measured using a plethysmometer (Ugo Basile, Comerio, Italy) monthly after the second immunization. After 4 months, 6month-old mice were sacrificed and examined for AD pathogenesis on the basis of amyloid plaques and cerebrovascular pathology.

\section{Analysis of plasma IL-1 $\beta$ and TNF- $\alpha$}

Plasma cytokine levels were analyzed at various time points after the secondary injections of CII in CFA. Blood was collected via cardiac puncture and then transferred into a heparin-coated tube (Becton Dickinson, USA). The tube was placed on ice and centrifuged at $5000 \mathrm{rpm}(1500 \mathrm{~g})$ for $3 \mathrm{~min}$. The supernatant was collected and stored at $-80^{\circ} \mathrm{C}$. Plasma levels of IL-1 $\beta$ and TNF- $\alpha$ were measured with a commercial ELISA kit (Biosource, Camarillo, CA, USA) according to the manufacturer's instructions.

\section{Tissue preparation}

Animals were anesthetized with an intraperitoneal injection of chloral hydrate $(400 \mathrm{mg} / \mathrm{kg})$ and transcardially perfused with $0.9 \% \mathrm{NaCl}$. The right hind paw injected with CII in CFA was removed, fixed in $10 \%$ formalin solution at $4^{\circ} \mathrm{C}$ for $24 \mathrm{~h}$, and decalcified in 10\% EDTA solution at $4^{\circ} \mathrm{C}$ for 3 weeks. The tissues were then embedded in paraffin and cut into 8 - $\mu$ m-thick sections. The right brain hemisphere was immersion-fixed with $4 \%$ paraformaldehyde for $24 \mathrm{~h}$, cryoprotected in $30 \%$ sucrose for $48 \mathrm{~h}$, and cut into 18- $\mu \mathrm{m}$-thick coronal cryosections. The hippocampal formation and cortex were dissected out from the left hemisphere and frozen at $-80^{\circ} \mathrm{C}$ for protein assay. 


\section{A $\beta$ ELISA}

Combined cortical and hippocampal tissues were homogenized in $0.5 \mathrm{ml}$ Tris-buffered saline (TBS) containing protease inhibitor cocktail (Calbiochem, San Diego, CA, USA) and centrifuged at $14,000 \mathrm{rpm}$ for $30 \mathrm{~min}$ at $4^{\circ} \mathrm{C}$. The supernatant was collected and stored at $-80^{\circ} \mathrm{C}$ for Western blot analysis of IgG. The pellet was sonicated in $0.5 \mathrm{ml}$ of $2 \%$ SDS in TBS and centrifuged at 14,000 rpm for $40 \mathrm{~min}$ at $4^{\circ} \mathrm{C}$. The supernatant was used for analysis of soluble $A \beta$. For analysis of insoluble $A \beta$, the pellet was sonicated with $0.5 \mathrm{ml} 70 \%$ formic acid in water and then neutralized by 1:40 dilution into $1 \mathrm{M}$ Tris-phosphate buffer ( $\mathrm{pH}$ 11.0). Levels of $\mathrm{A} \beta 40$ and A $\beta 42$ were analyzed using an ELISA kit (Biosource, Camarillo, CA, USA) according to the manufacturer's instructions.

\section{Immunohistochemistry}

Brain sections were washed in phosphate-buffered saline, incubated in washed in $0.3 \% \mathrm{H}_{2} \mathrm{O}_{2}$ and $0.25 \%$ Triton $\mathrm{X}-100$ for $10 \mathrm{~min}$ at room temperature, and reacted with $10 \%$ horse serum for $1 \mathrm{~h}$. Sections were then reacted overnight at $4{ }^{\circ} \mathrm{C}$ with one of the following primary antibodies: mouse monoclonal anti-4G8 (1:1000, Signet), rat monoclonal anti-CD45 (1:500, Serotec), rabbit polyclonal anti-Iba-1 (1:1000, WAKO), rat monoclonal anti-Mac-1 (1:500, Serotec), goat polyclonal anti-IL$1 \beta(1: 200, R \& D)$, goat anti-polyclonal anti-TNF- $\alpha$ (1:200, R\&D), rat monoclonal anti-CD206 (1:500, Serotec), and rabbit polyclonal anti-collagen type IV (1:500, Millipore). For 4G8 immunostaining, sections were pretreated with $70 \%$ formic acid for 10 min to expose the A $\beta$ epitope. The sections were reacted with anti-mouse, anti-rat, or anti-rabbit IgG fluorescent or biotin-conjugated (Vector, Burlingame, CA, USA) secondary antibody for $2 \mathrm{~h}$. The biotin-labeled sections were incubated with avidin-biotin-peroxidase complex (ABC Elite kit, Vector) for $1 \mathrm{~h}$ and then visualized using 3,3'-diaminobenzidine tetrahydrochloride dehydrate (DAB, Vector).

\section{Image analysis of amyloid plaque burden, activated microglia/macrophages, and vascular pathology}

Brain sections containing the hippocampal formation and cortex were immunolabeled with an antibody to 4G8 (amyloid plaque burden), CD45 (activated microglia/macrophage), or collagen type IV (vascular pathology). To identify amyloid plaques using thioflavine-S staining, the brain sections were incubated in $1 \%$ aqueous thioflavine-S (Sigma) for $10 \mathrm{~min}$, followed by dehydration with $70 \%$ ethyl alcohol, and coverslipped with mounting medium. Three sections on the anatomically comparable plane for each animal were analyzed using MetaMorph 6.1 software (Universal Imaging Corp, Downingtown, PA, USA). The immunostained sections were captured using an Olympus BX 51 microscope (Olympus, Japan) at a magnification of $200 \times$. The areas positive for 4G8, thioflavine-S, or CD45 in the hippocampal formation and cortex were subtracted from nonspecific signal from the same section and scaled to the vehicle group $(=100)$. The vascular pathology was analyzed in the area including the CA1 pyramidal layer and cortex by measuring vessel density and length immunolabeled with collagen type IV.

\section{Western blotting}

BBB permeability was investigated by monitoring levels of IgG. Combined cortical and hippocampal samples (see above) were electrophoresed on an 8-10\% SDS polyacrylamide gel and transferred to a nitrocellulose membrane. The membrane was pre-incubated with $5 \%$ nonfat dry milk and reacted with a biotinylated antimouse lgG (1:500, Vector) overnight at $4^{\circ} \mathrm{C}$. The membrane was then reacted with avidin-biotin-peroxidase complex (ABC Elite kit, Vector) for $2 \mathrm{~h}$ and then with enhanced chemiluminescence reagents (Amersham, Buckinghamshire, UK) on X-ray film. Band intensity was quantified using Image Gauge 3.12 (Fuji PhotoFilm Co). The blot was stripped and probed with rabbit polyclonal anti-actin (1:1000, Sigma) to normalize the protein load among samples.

\section{Statistical analysis}

All values are expressed as mean \pm S.E.M. An independent-samples $t$-test was used to compare two samples. Analysis of variance (ANOVA) and the Student-Newman-Keuls test were used for multiple comparisons. All analyses were calculated using SPSS version 12.0 for Windows. Statistical significance was assumed at $P<$ 0.05 .

\section{Additional material}

Additional file 1: Figure S1 - Transient increase of microglial cell
proliferation in wild-type mice treated with CIA. Photomicrographs of
the dentate gyrus molecular layer immunolabeled with Mac-1 after
second injection of CII in CFA in 2-month-old wild-type mice. The
number of Mac-1-immunoreactive microglial cells was increased within 1
$d$ after second injection of CII in CFA. This increase remained for over 1
wk, but disappeared within 2 wks ( $n=4$ per group). Scale bar $=200 \mu \mathrm{m}$.
Additional file 2: Figure S2 - CIA increases mortality in APP/PS1
mice. Survival analysis of wild-type (Tg-) and APP/PS1 (Tg+) mice treated
with vehicle or CIA at 2 months of age (Tg-vehicle, $n=30 ; \mathrm{Tg}-\mathrm{CIA}, n=$
34; Tg+ vehicle, $n=30 ;$ and Tg+ CIA, $n=34)$.

\section{Acknowledgements}

This work was supported by grants from the Korea Research Foundation (KRF 2011-0012732), the 21C Frontier R\&D Program in Neuroscience from Ministry of Education, Science and Technology, and GNT Pharma. 


\section{Author details}

'Department of Pharmacology, Ajou University School of Medicine, Suwon, South Korea. ${ }^{2}$ Clinical research center, Samsung biomedical research institute, Seoul, South Korea. ${ }^{3}$ GNT Pharma, Suwon, South Korea.

\section{Authors' contributions}

SMP performed most experiments and JHS, GJM, SIC, and YBL participated in the discussion of data. BJG carried out the design of the study, interpretation of the data and preparation of the manuscript. All authors read and approved the final manuscript.

Received: 15 August 2011 Accepted: 27 October 2011 Published: 27 October 2011

\section{References}

1. Masters $C L$, Simms G, Weinman NA, Multhaup G, McDonald BL, Beyreuther K: Amyloid plaque core protein in Alzheimer disease and Down syndrome. Proc Natl Acad Sci USA 1985, 82:4245-4249.

2. Selkoe DJ: The molecular pathology of Alzheimer's disease. Neuron 1991 6:487-498

3. Farkas E, Luiten PG: Cerebral microvascular pathology in aging and Alzheimer's disease. Prog Neurobiol 2001, 64:575-611.

4. McGeer PL, Itagaki S, Tago H, McGeer EG: Reactive microglia in patients with senile dementia of the Alzheimer type are positive for the histocompatibility glycoprotein HLA-DR. Neurosci Lett 1987, 79:195-200.

5. Zaciragic A, Lepara O, Valjevac A, Arslanagic S, Fajkic A, Hadzovic-Dzuvo A Avdagic N, Alajbegovic A, Mehmedika-Suljic E, Coric G: Elevated serum Creactive protein concentration in Bosnian patients with probable Alzheimer's disease. J Alzheimers Dis 2007, 12:151-156.

6. Holmes C, Cunningham C, Zotova E, Woolford J, Dean C, Kerr S, Culliford D, Perry VH: Systemic inflammation and disease progression in Alzheimer disease. Neurology 2009, 73:768-774.

7. Tan ZS, Beiser AS, Vasan RS, Roubenoff R, Dinarello CA, Harris TB, Benjamin EJ, Au R, Kiel DP, Wolf PA, Seshadri S: Inflammatory markers and the risk of Alzheimer disease: the Framingham Study. Neurology 2007 68:1902-1908.

8. Mancinella A, Mancinella M, Carpinteri G, Bellomo A, Fossati C, Gianturco V, Iori A, Ettorre E, Troisi G, Marigliano V: Is there a relationship between high C-reactive protein (CRP) levels and dementia? Arch Gerontol Geriatr 2009, 49(Suppl 1):185-194.

9. Pachter JS: Inflammatory mechanisms in Alzheimer disease: the role of beta-amyloid/glial interactions. Mol Psychiatry 1997, 2:91-95.

10. Griffin WS, Sheng JG, Roberts GW, Mrak RE: Interleukin-1 expression in different plaque types in Alzheimer's disease: significance in plaque evolution. J Neuropathol Exp Neurol 1995, 54:276-281.

11. Dickson DW, Lee SC, Mattiace LA, Yen SH, Brosnan C: Microglia and cytokines in neurological disease, with special reference to AIDS and Alzheimer's disease. Glia 1993, 7:75-83.

12. Meda L, Cassatella MA, Szendrei Gl, Otvos L, Baron P, Villalba M, Ferrari D, Rossi F: Activation of microglial cells by beta-amyloid protein and interferon-gamma. Nature 1995, 374:647-650

13. Meda L, Baron P, Scarlato G: Glial activation in Alzheimer's disease: the role of Abeta and its associated proteins. Neurobiol Aging 2001, 22:885-893.

14. Etminan $M$, Gill S, Samii A: Effect of non-steroidal anti-inflammatory drugs on risk of Alzheimer's disease: systematic review and meta-analysis of observational studies. BMJ 2003, 327:128.

15. McGeer PL, Schulzer M, McGeer EG: Arthritis and anti-inflammatory agents as possible protective factors for Alzheimer's disease: a review of 17 epidemiologic studies. Neurology 1996, 47:425-432.

16. Lim GP, Yang F, Chu T, Chen P, Beech W, Teter B, Tran T, Ubeda O, Ashe $\mathrm{KH}$, Frautschy SA, Cole GM: Ibuprofen suppresses plaque pathology and inflammation in a mouse model for Alzheimer's disease. J Neurosci 2000, 20:5709-5714.

17. Lim GP, Yang F, Chu T, Gahtan E, Ubeda O, Beech W, Overmier JB, HsiaoAshec K, Frautschy SA, Cole GM: Ibuprofen effects on Alzheimer pathology and open field activity in APPsw transgenic mice. Neurobiol Aging 2001, 22:983-991.

18. Kotilinek LA, Westerman MA, Wang Q, Panizzon K, Lim GP, Simonyi A, Lesne S, Falinska A, Younkin LH, Younkin SG, et al: Cyclooxygenase-2 inhibition improves amyloid-beta-mediated suppression of memory and synaptic plasticity. Brain 2008, 131:651-664.

19. Szekely CA, Zandi PP: Non-steroidal anti-inflammatory drugs and Alzheimer's disease: the epidemiological evidence. CNS Neurol Disord Drug Targets 2010, 9:132-139.

20. Bresalier RS, Sandler RS, Quan H, Bolognese JA, Oxenius B, Horgan K, Lines C, Riddell R, Morton D, Lanas A, et al: Cardiovascular events associated with rofecoxib in a colorectal adenoma chemoprevention trial. N Engl J Med 2005, 352:1092-1102.

21. Breitner JC, Baker LD, Montine TJ, Meinert CL, Lyketsos CG, Ashe $\mathrm{KH}$ Brandt J, Craft S, Evans DE, Green RC, et al: Extended results of the Alzheimer's disease anti-inflammatory prevention trial. Alzheimers Dement 2011, 7:402-411.

22. Boyd TD, Bennett SP, Mori T, Governatori N, Runfeldt M, Norden M Padmanabhan J, Neame P, Wefes I, Sanchez-Ramos J, et al: GM-CSF upregulated in rheumatoid arthritis reverses cognitive impairment and amyloidosis in Alzheimer mice. J Alzheimers Dis 2010, 21:507-518.

23. Brand DD, Latham KA, Rosloniec EF: Collagen-induced arthritis. Nat Protoc 2007, 2:1269-1275

24. Jankowsky JL, Fadale DJ, Anderson J, Xu GM, Gonzales V, Jenkins NA, Copeland NG, Lee MK, Younkin LH, Wagner SL, et al: Mutant presenilins specifically elevate the levels of the 42 residue beta-amyloid peptide in vivo: evidence for augmentation of a 42-specific gamma secretase. Hum Mol Genet 2004, 13:159-170.

25. Benzing WC, Wujek JR, Ward EK, Shaffer D, Ashe KH, Younkin SG, Brunden KR: Evidence for glial-mediated inflammation in aged APP(SW) transgenic mice. Neurobiol Aging 1999, 20:581-589.

26. Mehlhorn $\mathrm{G}$, Hollborn M, Schliebs R: Induction of cytokines in glial cells surrounding cortical beta-amyloid plaques in transgenic Tg2576 mice with Alzheimer pathology. Int J Dev Neurosci 2000, 18:423-431.

27. Jimenez S, Baglietto-Vargas D, Caballero C, Moreno-Gonzalez I, Torres M, Sanchez-Varo R, Ruano D, Vizuete M, Gutierrez A, Vitorica J: Inflammatory response in the hippocampus of PS1M146L/APP751SL mouse model of Alzheimer's disease: age-dependent switch in the microglial phenotype from alternative to classic. J Neurosci 2008, 28:11650-11661.

28. Nishioku T, Yamauchi A, Takata F, Watanabe T, Furusho $K$, Shuto $H$, Dohgu S, Kataoka Y: Disruption of the blood-brain barrier in collageninduced arthritic mice. Neurosci Lett 2010, 482:208-211.

29. Rezai-Zadeh K, Gate D, Town T: CNS infiltration of peripheral immune cells: D-Day for neurodegenerative disease? J Neuroimmune Pharmacol $2009,4: 462-475$

30. Xiang Z, Ho L, Yemul S, Zhao Z, Qing W, Pompl P, Kelley K, Dang A, Teplow D, Pasinetti GM: Cyclooxygenase-2 promotes amyloid plaque deposition in a mouse model of Alzheimer's disease neuropathology. Gene Expr 2002, 10:271-278.

31. Morihara T, Teter B, Yang F, Lim GP, Boudinot S, Boudinot FD, Frautschy SA, Cole GM: Ibuprofen suppresses interleukin-1beta induction of proamyloidogenic alpha1-antichymotrypsin to ameliorate beta-amyloid (Abeta) pathology in Alzheimer's models. Neuropsychopharmacology 2005, 30:1111-1120.

32. Hoshino T, Nakaya T, Homan T, Tanaka K, Sugimoto Y, Araki W, Narita M, Narumiya S, Suzuki T, Mizushima T: Involvement of prostaglandin E2 in production of amyloid-beta peptides both in vitro and in vivo. $J$ Biol Chem 2007, 282:32676-32688.

33. Nagano T, Kimura SH, Takemura M: Prostaglandin E2 reduces amyloid beta-induced phagocytosis in cultured rat microglia. Brain Res 2010, 1323:11-17.

34. Wyss-Coray T, Lin C, Yan F, Yu GQ, Rohde M, McConlogue L, Masliah E, Mucke L: TGF-beta1 promotes microglial amyloid-beta clearance and reduces plaque burden in transgenic mice. Nat Med 2001, 7:612-618.

35. Chakrabarty $P$, Jansen-West $K$, Beccard A, Ceballos-Diaz C, Levites $Y$ Verbeeck C, Zubair AC, Dickson D, Golde TE, Das P: Massive gliosis induced by interleukin- 6 suppresses Abeta deposition in vivo: evidence against inflammation as a driving force for amyloid deposition. FASEB $\rfloor$ 2010, 24:548-559.

36. Tsai K, Tsai YC, Shen CK: G-CSF rescues the memory impairment of animal models of Alzheimer's disease. J Exp Med 2007, 204:1273-1280.

37. Boissonneault V, Filali M, Lessard M, Relton J, Wong G, Rivest S: Powerful beneficial effects of macrophage colony-stimulating factor on betaamyloid deposition and cognitive impairment in Alzheimer's disease. Brain 2009, 132:1078-1092. 
38. Stahl T, Reimers C, Johne R, Schliebs R, Seeger J: Viral-induced inflammation is accompanied by beta-amyloid plaque reduction in brains of amyloid precursor protein transgenic Tg2576 mice. Eur J Neurosci 2006, 24:1923-1934.

39. Wyss-Coray T, Yan F, Lin AH, Lambris JD, Alexander JJ, Quigg RJ, Masliah E: Prominent neurodegeneration and increased plaque formation in complement-inhibited Alzheimer's mice. Proc Natl Acad Sci USA 2002, 99:10837-10842.

40. Vukic V, Callaghan D, Walker D, Lue LF, Liu QY, Couraud PO, Romero IA Weksler B, Stanimirovic DB, Zhang W: Expression of inflammatory genes induced by beta-amyloid peptides in human brain endothelial cells and in Alzheimer's brain is mediated by the JNK-AP1 signaling pathway. Neurobiol Dis 2009, 34:95-106.

41. Fiala M, Zhang L, Gan X, Sherry B, Taub D, Graves MC, Hama S, Way D, Weinand $M$, Witte $M$, et al: Amyloid-beta induces chemokine secretion and monocyte migration across a human blood-brain barrier model. Mol Med 1998, 4:480-489.

42. El Khoury J, Toft M, Hickman SE, Means TK, Terada K, Geula C, Luster AD: Ccr2 deficiency impairs microglial accumulation and accelerates progression of Alzheimer-like disease. Nat Med 2007, 13:432-438.

43. Xu WD, Firestein GS, Taetle R, Kaushansky K, Zvaifler NJ: Cytokines in chronic inflammatory arthritis. II. Granulocyte-macrophage colonystimulating factor in rheumatoid synovial effusions. J Clin Invest 1989, 83:876-882.

44. Nakamura H, Ueki Y, Sakito S, Matsumoto K, Yano M, Miyake S, Tominaga T, Tominaga $M$, Eguchi $K$ : High serum and synovial fluid granulocyte colony stimulating factor (G-CSF) concentrations in patients with rheumatoid arthritis. Clin Exp Rheumatol 2000, 18:713-718.

45. Chomarat P, Banchereau J, Davoust J, Palucka AK: IL-6 switches the differentiation of monocytes from dendritic cells to macrophages. Nat Immunol 2000, 1:510-514

46. Alonzi T, Fattori E, Lazzaro D, Costa P, Probert L, Kollias G, De Benedetti F, Poli V, Ciliberto G: Interleukin 6 is required for the development of collagen-induced arthritis. J Exp Med 1998, 187:461-468.

47. Ito S, Sawada M, Haneda M, Fujii S, Oh-Hashi K, Kiuchi K, Takahashi M, Isobe K: Amyloid-beta peptides induce cell proliferation and macrophage colony-stimulating factor expression via the PI3-kinase/Akt pathway in cultured Ra2 microglial cells. FEBS Lett 2005, 579:1995-2000.

48. Carrano A, Hoozemans JJ, van der Vies SM, Rozemuller AJ, van Horssen J, de Vries HE: Amyloid beta Induces Oxidative Stress-Mediated Blood-Brain Barrier Changes in Capillary Amyloid Angiopathy. Antioxid Redox Signal 2011.

49. Xu J, Chen S, Ku G, Ahmed SH, Chen H, Hsu CY: Amyloid beta peptideinduced cerebral endothelial cell death involves mitochondrial dysfunction and caspase activation. J Cereb Blood Flow Metab 2001, 21:702-710.

50. Sousa MM, Du Yan S, Fernandes R, Guimaraes A, Stern D, Saraiva MJ: Familial amyloid polyneuropathy: receptor for advanced glycation end products-dependent triggering of neuronal inflammatory and apoptotic pathways. J Neurosci 2001, 21:7576-7586.

51. Romanelli MF, Morris JC, Ashkin K, Coben LA: Advanced Alzheimer's disease is a risk factor for late-onset seizures. Arch Neurol 1990, 47:847-850.

52. Palop JJ, Chin J, Roberson ED, Wang J, Thwin MT, Bien-Ly N, Yoo J, Ho KO, Yu GQ, Kreitzer A, et al: Aberrant excitatory neuronal activity and compensatory remodeling of inhibitory hippocampal circuits in mouse models of Alzheimer's disease. Neuron 2007, 55:697-711.

53. Minkeviciene R, Rheims S, Dobszay MB, Zilberter M, Hartikainen J, Fulop L, Penke B, Zilberter Y, Harkany T, Pitkanen A, Tanila H: Amyloid beta-induced neuronal hyperexcitability triggers progressive epilepsy. J Neurosci 2009, 29:3453-3462

54. Kitazawa M, Oddo S, Yamasaki TR, Green KN, LaFerla FM: Lipopolysaccharide-induced inflammation exacerbates tau pathology by a cyclin-dependent kinase 5-mediated pathway in a transgenic model of Alzheimer's disease. J Neurosci 2005, 25:8843-8853.

55. Jankowsky $J$, Slunt HH, Ratovitski T, Jenkins NA, Copeland NG, Borchelt DR: Co-expression of multiple transgenes in mouse CNS: a comparison of strategies. Biomol Eng 2001, 17:157-165. doi:10.1186/1471-2202-12-106

Cite this article as: Park et al:: Effects of collagen-induced rheumatoid arthritis on amyloidosis and microvascular pathology in APP/PS1 mice. BMC Neuroscience 2011 12:106.

\section{Submit your next manuscript to BioMed Central and take full advantage of:}

- Convenient online submission

- Thorough peer review

- No space constraints or color figure charges

- Immediate publication on acceptance

- Inclusion in PubMed, CAS, Scopus and Google Scholar

- Research which is freely available for redistribution 